\title{
ANALISIS KETAHANAN PANGAN RUMAH TANGGAMISKIN BERDASARKAN PANGSA PENGELUARAN PANGAN DANKONSUMSI ENERGI DI DESA GIRIREJO KECAMATAN IMOGIRIKABUPATEN BANTUL
}

\author{
The Resilience of Food Household Poor House Based on Food Expenditure \\ and Energy Consumption in Girirejo, \\ Imogiri District, Bantul District
}

\author{
Zikro Rahmansyah*, Nanik Dara Senjawati, Juarini \\ Program Studi Agribisnis Jurusan Agribisnis Fakultas Pertanian \\ Universitas Pembangunan Nasional "Veteran" Yogyakarta \\ Jl. SWK 104 (Lingkar Utara) Codong Catur Yogyakarta, Indonesia 55283 \\ *Email korespondensi: zikro.rahman36@gmail.com
}

Diterima tanggal : 9 Juni 2020 ; Disetujui tanggal 29 Juni 2020

\begin{abstract}
Objective of this research was to analyze the share of food expenditure, energy consumption and food security level. The basic method of research is descriptive analysis. Method of implementation used survey method. Location ofthis research was determined by using purposive sampling. This research was conducted in Girirejo Village, Imogiri District, Bantul Regency. Respondents as many as 41 Program Keluarga Harapan (PKH) recipient households were selected using simple random sampling method. The data used primary and secondary data. Analysis of food expenditure share calculated by using ratio distribution of food expenditure and total household expenditure, the assessment of household food consumption was measured by quantity of food consumption. The level of food security at the household was measured by cross-classification of two indicators food security, namely the share of food expenditure and the level of energy consumption. The results showed that the share of food expenditure amount of $87.45 \%$, the level of energy consumption as much as $96.04 \%$, and the food security conditions of PKH recipient households in Girirejo Village categorized food insecure.
\end{abstract}

Keywords: Energy Consumption, Food Expenditures Share, Food Security 
Jurnal Dinamika Sosial Ekonomi, 21 (1) : 58-78

\begin{abstract}
ABSTRAK
Penelitian ini dilakukan di Desa Girirejo, Kecamatan Imogiri, Kabupaten Bantul. Tujuan penelitian adalah menganalisis pangsa pengeluaran pangan, konsumsi energi, dan tingkat ketahanan pangan. Metode dasar penelitian adalah metode deskriptif analitis. Metode pemilihan lokasi penelitian dengan purposive sampling. Responden sebanyak 41 rumah tangga penerima PKH (Program Keluarga Harapan) yang dipilih menggunakan metode simple random sampling. Data yang digunakan adalah data primer dan sekunder yang diperoleh melalui observasi, wawancara, dan pencatatan pangan food recall 24 jam. Analisis pangsa pengeluaran pangan dapat dihitung menggunakan pengeluaran pangan terhadap pengeluaran total rumah tangga dengan uji one sample t-test, dan penilaian tingkat konsumsi energi rumah tanggadianalisis dengan uji one sample t-test.Indikator yang digunakan untuk mengukur derajat ketahanan pangan tingkat rumah tangga menggunakanklasifikasi silang dua indikator ketahanan pangan, yaitu pangsa pengeluaran pangan dan tingkat konsumsi energi. Hasil penelitian menunjukkan pangsa pengeluaran pangan sebesar $87,45 \%$ yang menunjukkan bahwa pangsa pengeluaran pangan dalam kategori tinggi, tingkat konsumsi energi sebesar 96,04 $\%$ yang menunjukkan bahwa tingkat konsumsi energi dalam kategori cukup, dan kondisi ketahanan pangan rumah tangga penerima PKH di Desa Girirejo termasuk kategori rentan pangan.
\end{abstract}

Kata Kunci: Ketahanan Pangan, Konsumsi Energi, Pangsa Pengeluaran Pangan

\title{
PENDAHULUAN
}

Suatu wilayah dikatakan berhasil dalam pembangunan ketahanan pangan jika adanya peningkatan produksi pangan, distribusi pangan yang lancar serta konsumsi pangan yang aman dan berkecukupan gizi pada seluruh masyarakat.Ketahanan pangan terdiri dari 3 dimensi, yaitu 1) Ketersedian Pangan (Food Availability), 2) Akses Pangan (Food Access), 3) Penyerapan Pangan (Food Utilization) (Adriani \& Wirtjatmadi, 2012). Sesuatu yang diyakini para ahli adalah apabila salah satu dari dimensi tersebut tidak terpenuhi, suatu Negara belum dapat dikatakan mempunyai ketahanan pangan yang baik. Walaupun pangan tersedia cukup di tingkat nasional dan regional, jika akses individu untuk memenuhi kebutuhan pangannya tidak merata, ketahanan pangan masih dikatakan rapuh (Fagi, 2013). Demikian pula, walaupun ketersediaan dan aksesbilitas masyarakat dapat dikatakan cukup, jika stabilitas harga pangan tidak mampu terjaga secara baik (dan tentunyaberakibat pada ketersediaan dan aksesbilitas), ketahanan pangan tidak dapat dikatakan telah cukup kuat (Arifin, 2007). 
Rahmansyah et.al., Analisis Ketahanan Pangan Rumah Tanggamiskin...

Peningkatan ketahanan pangan merupakan prioritas utama dalam pembangunan karena pangan merupakan kebutuhan yang paling dasar bagi manusia sehingga pangan sangat berperan dalam pertumbuhan ekonomi nasional (Rachman, Handewi dan Ariani, Mewa, 2002). Indikator yang digunakan untuk mengukur derajat ketahanan pangan tingkat rumah tangga adalah klasifikasi silang dua indikator ketahanan pangan, yaitu pangsa pengeluaran pangan dan tingkat konsumsi energi (Putri, et al., 2013). Kategori rumah tangga berdasarkan indikator ketahanan pangan ada 4 kategori antara lain tahan pangan, rentan pangan, kurang pangan, dan rawan pangan. Pemerintah telah melakukan berbagai upaya untuk mengatasi masalah ketahanan pangan, salah satunya dengan memastikan pemenuhan kebutuhan pangan sehari-hari karena keadaaan ketahanan pangan yang rentan dan rawan dapat menjadi sumber kemiskinan (Mulyo, et.al.,2015).

Dalam rangka penanggulangankemiskinan, pemerintah meluncurkan program khusus yang diberi nama Program Keluarga Harapan (PKH) yang merupakan program pemberian bantuan sosial bersyarat kepada Keluarga Miskin yang ditetapkan sebagai penerima manfaat PKH untuk menanggulangi masalah kemiskinan (Fauzi, et,al.,2019).Desa Girirejo merupakan satu desa yang unik di Kabupaten Bantul, desa yang dapat mencapai kemandirian pangan sejak tahun 2017 sebelumnya berproses menjadi Desa Replikasi Mandiri Pangan selama tiga tahun (Dinas Pertanian Pangan Kelautan Kabupaten Bantul, 2019), tetapi desa ini memiliki jumlah rumah tangga yang menerima bantuan PKH sebanyak $620 \mathrm{KK}$ dari total penduduk Desa Girirejo sebanyak 1563 KK diketahui presentasenya sebesar $39,66 \%$, padahal desa ini memiliki potensi sumber daya alam yang baik (Buku Monografi Desa, 2019).

Menurut Dinas Sosial Daerah Istimewa Yogyakarta menyebutkan bahwa Desa Girirejo merupakan salah satu desa yang menjadi lokasi konsentrasi Pemerintah Daerah Istimewa Yogyakarta yang merupakan kantong-kantong kemiskinan di DIY (PKH Jogja Istimewa, 2018). Desa Girirejo secara spesifik perlu diteliti bagaimana tingkat pangsa pengeluaran pangan dan konsumsi energi rumah tangga untuk mengetahui tingkat ketahanan pangan.Berdasarkan latar belakang tersebut, penelitian ini bertujuan untuk menganalisis pangsa pengeluaran 
Jurnal Dinamika Sosial Ekonomi, 21 (1) : 58-78

pangan, konsumsi energi, dan tingkat ketahanan pangan di Desa Girirejo, Kecamatan Imogiri, Kabupaten Bantul.

\section{METODE PENELITIAN}

Metode pelaksanaan penelitian yang digunakan adalah metode survei. Metode survei menurut (Sugiyono, 2016) adalah penelitian yang dilakukan dengan menggunakan angket sebagai alat penelitian yang dilakukan pada populasi besar maupun kecil, tetapi data yang dipelajari adalah data dari sampel yang diambil dari populasi tersebut, sehingga ditemukan kejadian relatif, distribusi, dan hubungan antar variabel, sosiologis maupun psikologis dengan tujuan untuk memberikan gambaran secara mendetail tentang latar belakang, sifat-sifat, serta karakter-karakter yang khas dari kasus atau kejadian suatu hal yang bersifat umum.Metode pengambilan daerah penelitian dilakukan dengan metode purposivesampling, yaitu penentuan daerah sampel yang diambil secara sengajaberdasarkan pertimbangan-pertimbangan tertentu (Surakhmad, 1994 dalam Wahyuni, 2012). Pemilihan daerah penelitian berdasarkan pertimbangan bahwa daerah tersebut tergolong DesaMandiri Pangan baru di Kabupaten Bantul yaitu Desa Girirejo.

\section{Analisis Pangsa Pengeluaran Pangan}

Analisis pangsa pengeluaran pangan dapat dihitung menggunakan rumus pembagian antara pengeluaran pangan terhadap pengeluaran total rumah tangga:

$$
\mathrm{PF}=\frac{P P_{t}}{T P_{t}} \times 100 \%
$$

Di mana:

$\mathrm{PF}=$ Pangsa pengeluaran pangan rumah tangga $(\%)$

$\mathrm{PPt}=$ Pengeluaran untuk pangan $(\mathrm{Rp} / \mathrm{bulan})$

$\mathrm{TPt}=$ Total pengeluaran $($ pangan dan non pangan $)(\mathrm{Rp} / \mathrm{bulan})$

Jika pangsa pengeluaran pangan kurang dari $60 \%$ maka rumah tangga tersebut tahan pangan, tetapi jika pangsa pengeluaran pangan lebih dari sama dengan 60\% maka rumah tangga tersebut rawan pangan (Maxwell et al., 2000 dalam Wahyuni, 2012). 
Rahmansyah et.al., Analisis Ketahanan Pangan Rumah Tanggamiskin...

\section{Analisis Tingkat Konsumsi Energi}

Konsumsi dapat diketahui dengan melihat besarnya konsumsi pangan masing-masing rumah tangga miskin yang kemudian dikonversikan ke dalam bentuk konsumsi energi (kkal/orang/hari). Pengkonversian dilakukan dengan menggunakan Daftar Komposisi Bahan Makanan (DKBM) (Prasetyaningtyas, 2017)

Penilaian konsumsi pangan rumah tangga dapat dilihat dari dua sisi, yaitu kualitas dan kuantitas konsumsi pangan (Sinaga, 2012). Dalam penelitian ini, penelitian konsumsi pangan akan dilihat dari aspek kuantitas pangan untuk menentukan ketahanan pangan tingkat rumah tangga. Kuantitas konsumsi pangan dapat diukur dari zat gizi yang terkandung dalam bahan pangan. Data konsumsi pangan dapat diperoleh menggunakan recall method selama 1 x 24 jam (Supriasa, 2002 dalam Wahyuni, 2012). Dalam metode ini, responden diminta menceritakan semua pangan yang dimakan dan diminum selama 24 jam yang lalu. Jumlah konsumsi pangan dinyatakan dengan URT (Ukuran Rumah Tangga) seperti sendok, gelas, potong, dan sebagainya. URT akan dikonversi ke dalam satuan gram sesuai dengan ukuran yang berlaku di daerah penelitian.

Secara umum penilaian jumlah zat gizi yang dikonsumsi dihitung sebagai berikut :

$G i j=\frac{B P j}{100} \times \frac{B d d j}{100} \times K G i j$

Di mana :

$\mathrm{G}_{\mathrm{ij}} \quad$ : Jumlah energi atau protein yang dikonsumsi dari pangan $\mathrm{j}$ (energi dalam satuan kilokalori dan protein dalam satuan gram)

$\mathrm{BP}_{\mathrm{j}}$ : Berat pangan j yang dikonsumsi (gram)

Bdd $_{\mathrm{j}}$ : Bagian yang dapat dimakan dari 100 gram pangan $\mathrm{j}(\%)$

$\mathrm{KG}_{\mathrm{ij}}$ : Kandungan energi atau protein per 100 gram pangan $\mathrm{j}$ yang dikonsumsi (energi dalam satuan kilokalori dan protein dalam satuan gram)

Kuantitas konsumsi pangan ditinjau dari volume pangan yang dikonsumsi dan konsumsi zat gizi yang dikandung dalam bahan pangan. Kedua hal ini digunakan untuk mengetahui apakah konsumsi pangan sudah cukup memenuhi 
Jurnal Dinamika Sosial Ekonomi, 21 (1) : 58-78

kebutuhan yang layak untuk hidup sehat (AKG). Untuk menilai konsumsi pangan secara kuantitatif digunakan parameter Tingkat Konsumsi Energi (TKE).

$\mathrm{TKE}=\frac{\sum \text { Konsumsi Energi }}{\text { AKE yang dianjurkan }} \times 100 \%$

Dimana :

TKE : Tingkat Konsumsi Energi (\%)

$\sum$ Konsumsi Energi : Jumlah Konsumsi Energi (kkal/orang/hari)

\section{Analisis Tingkat Ketahanan Pangan}

Indikator yang digunakan untuk mengukur derajat ketahanan pangan tingkat rumah tangga adalah klasifikasi silang dua indikator ketahanan pangan, yaitu pangsa pengeluaran pangan dan tingkat konsumsi energi. Kategori rumah tangga berdasarkan indikator ketahanan pangan dapat dilihat pada Tabel 1.

Tabel 1. Kategori Rumah Tangga Berdasarkan Indikator KetahananPangan

\begin{tabular}{ccc}
\hline \multirow{2}{*}{ Konsumsi Energi } & \multicolumn{2}{c}{ Pangsa Pengeluaran Pangan } \\
\cline { 2 - 3 }$(<60 \%$ pengeluaran total $)$ & $\begin{array}{c}\text { Tinggi } \\
(\geq 60 \% \text { pengeluaran total })\end{array}$ \\
\hline $\begin{array}{c}\text { Cukup } \\
(>80 \% \text { kecukupan energi }) \\
\text { Kurang }\end{array}$ & 1. Tahan Pangan & 2. Rentan Pangan \\
$(\leq 80 \%$ kecukupan energi $)$ & 3. Kurang Pangan & 1. Rawan Pangan \\
\hline
\end{tabular}

Sumber : Maxwell, 2000 dalam Ambarsari, 2017

Rumah tangga dikategorikan tahan pangan apabila memiliki pangsa pengeluaran pangan rendah (kurang dari 60\% dari pengeluaran rumah tangga) dan cukup mengkonsumsi energi (> 80\% syarat kecukupan energi). Rumah tangga rentan pangan didefinisikan sebagai rumah tangga yang memiliki pangsa pengeluaran pangan tinggi (> 60\% dari pengeluaran rumah tangga) namun cukup mengkonsumsi energi; rumah tangga kurang pangan apabila memiliki pangsa pengeluaran pangan rendah dan konsumsi energi kurang $(<80 \%$ dari syarat kecukupan). Sedangkan rumah tangga termasuk kategori rawan pangan apabila memiliki pangsa pengeluaran pangan tinggi dan tingkat konsumsi energinya kurang (Damayanti, 2007). 
Rahmansyah et.al., Analisis Ketahanan Pangan Rumah Tanggamiskin...

\section{HASIL DAN PEMBAHASAN}

\section{Pangsa Pengeluaran Pangan}

Pangsa pengeluaran pangan adalah pangsa pengeluaran rumah tangga untuk pangan terhadap total pengeluaran. Total pengeluaran didapatkan dengan menjumlahkan antara besarnya pengeluaran untuk pangan dan non pangan. Berikut merupakan tabel pengeluaran rumah tangga penerima PKH (Program Keluarga Harapan) di Desa Girirejo Kecamatan Imogiri Kabupaten Bantul pada tahun 2019.

Tabel 2. Rata-Rata Pengeluaran Rumah Tangga Penerima PKH di Desa Girirejo Kecamatan Imogiri Kabupaten Bantul

\begin{tabular}{lcc}
\hline \multicolumn{1}{c}{ Keterangan } & Jumlah (Rp/Bulan) & Persentase (\%) \\
\hline Pengeluaran Pangan & 1.087 .805 & 87,45 \\
Pengeluaran Non Pangan & 174.146 & 12,95 \\
\hline Jumlah & 1.259 .512 & 100 \\
\hline
\end{tabular}

Sumber : Analisis Data Primer, 2019

Pada Tabel 2 didapatkan nilai rata-rata pengeluaran pangan rumah tangga di Desa Girirejo Kecamatan Imogiri Kabupaten Bantul sebesarRp 1.087.805/Bulan atau $87,45 \%$ dan pengeluaran non pangan sebesar $\mathrm{Rp}$ 174.146/Bulan atau 12,95\% menunjukkan bahwa sebagian besar pendapatan digunakan untuk pengeluaran pangan yang berarti pangsa pengeluaran pangan di Desa Girirejo termasuk kategori tinggi.

\section{Konsumsi Energi}

Konsumsi gizi rumah tangga diketahui dengan menghitung konsumsi rumah tangga dalam waktu 24 jam yang lalu istilah lainnya adalah recallmethod dengan pedoman Daftar Komposisi Bahan Makanan (DKBM). Selanjutnya, konsumsi gizi ini dibandingkan dengan Angka Kecukupan Gizi (AKG) untuk mengetahui nilai Tingkat Konsumsi Gizi (TKG). Besarnya AKG berbeda-beda untuk setiap individu karena AKG ditentukan berdasarkan umur dan jenis 
Jurnal Dinamika Sosial Ekonomi, 21 (1) : 58-78

kelamin. Konsumsi energi adalah sejumlah energi pangan yang dikonsumsi per orang per hari yang dinyatakan dalam kkal/orang/hari.

Tabel 3. Rata-rata Konsumsi Energi Rumah Tangga Penerima PKH di Desa Girirejo Kecamatan Imogiri Kabupaten Bantul

\begin{tabular}{lc}
\hline \multicolumn{1}{c}{ Keterangan } & Jumlah (kkal) \\
\hline Total Energi Seharusnya (kkal) & 9.259 \\
Total Energi Riil (kkal) & $8.534,32$ \\
Kecukupan Energi (\%) & $96,04 \%$ \\
\hline
\end{tabular}

Sumber : Analisis Data Primer, 2019

Berdasarkan Tabel 3 dapat diketahui bahwa rata-rata total konsumsi energi seharusnya dalam rumah tangga Penerima PKH (Program Keluarga Harapan) di Desa Girirejo adalah sebesar 9.259 kkal sedangkan rata-rata total konsumsi energi rumah tangga penerima PKH di Desa Girirejo adalah sebesar 8.534,32 kkal, diperoleh kecukupan energi sebesar 96,04\% yang menunjukkan bahwa tingkat konsumsi energi dalam katergori cukup.

\section{Ketahanan Pangan}

Ketahanan pangan dapat dilihat dari tiga aspek, yaitu ketersediaan, konsumsi, dan distribusi (Nuraini, 2013). Dalam penelitian ini ketahanan pangan hanya dilihat melalui konsumsi pangan, terutama pada konsumsi energi. Berikut merupakan data mengenai kategori ketahanan pangan rumah tangga penerima PKH (Program Keluarga Harapan) di Desa Girirejo Kecamatan Imogiri Kabupaten Bantul. 
Rahmansyah et.al., Analisis Ketahanan Pangan Rumah Tanggamiskin...

Tabel 4. Jumlah Rumah Tangga Penerima PKH di Desa Girirejo Kecamatan Imogiri Kabupaten Bantul Menurut Kategori Ketahanan Pangan

\begin{tabular}{|c|c|c|c|c|}
\hline $\begin{array}{c}\text { Kategori Ketahanan } \\
\text { Pangan }\end{array}$ & $\begin{array}{c}\text { Pangsa } \\
\text { Pengeluaran } \\
\text { Pangan } \\
(\%)\end{array}$ & $\begin{array}{l}\text { Tingkat } \\
\text { Konsumsi } \\
\text { Energi (\%) }\end{array}$ & $\begin{array}{l}\text { Jumlah } \\
\text { Rumah } \\
\text { Tangga }\end{array}$ & $\begin{array}{c}\text { Persentase } \\
(\%)\end{array}$ \\
\hline $\begin{array}{l}\text { Tahan Pangan, jika pangsa } \\
\text { pengeluaran pangan }<60 \% \text {, konsumsi } \\
\text { energi cukup }(>80 \% \text { kecukupan } \\
\text { energi })\end{array}$ & 0 & 0 & 0 & 0 \\
\hline $\begin{array}{l}\text { Rentan Pangan, jika pangsa } \\
\text { pengeluaran pangan } \geq 60 \% \text {, konsumsi } \\
\text { energi cukup }(>80 \% \text { kecukupan } \\
\text { energi })\end{array}$ & 89,16 & 122,064 & 25 & 60,97 \\
\hline $\begin{array}{l}\text { Kurang Pangan, jika pangsa } \\
\text { pengeluaran pangan }<60 \% \text {, konsumsi } \\
\text { energi kurang }(\leq 80 \% \text { kecukupan } \\
\text { energi })\end{array}$ & 0 & 0 & 0 & 0 \\
\hline $\begin{array}{l}\text { Rawan Pangan, jika pangsa } \\
\text { pengeluaran pangan } \geq 60 \% \text {, konsumsi } \\
\text { energi kurang }(\leq 80 \% \text { kecukupan } \\
\text { energi })\end{array}$ & 84,80 & 51,86 & 16 & 39,02 \\
\hline Jumlah & & & 41 & 100 \\
\hline
\end{tabular}

Sumber : Analisis Data Primer, 2019

Pada umumnya, rumah tangga yang dikategorikan Penerima $\mathrm{PKH}$ (Program Keluarga Harapan) adalah rumah tangga yang rawan pangan atau tidak tahan pangan. Berdasarkan tabel 24 sejumlah 41 responden, tidak ada rumah tangga yang termasuk dalam rumah tangga tahan pangan dan kurang pangan. Hal ini disebabkan karena sebagian besar pendapatan yang diperoleh rumah tangga responden digunakan untuk memenuhi kebutuhan pangan. Kondisi ketahanan pangan rumah tangga miskin atau penerima PKH (Program Keluarga Harapan) yang rata-rata masuk dalam kategori rawan pangan sangat dipengaruhi oleh pendapatan suatu rumah tangga itu sendiri. Hal ini sangat mempengaruhi kuantitas dan kualitas makanan yang dikonsumsi. 
Jurnal Dinamika Sosial Ekonomi, 21 (1) : 58-78

\section{KESIMPULAN DAN SARAN}

\section{Kesimpulan}

Besarnya pangsa pengeluaran pangan adalah $87,45 \%$, artinya sebagian besar pengeluaran konsumsi rumah tangga penerima PKH digunakan untuk memenuhi kebutuhan pangan dalam kategori tinggi. Rata-rata konsumsi energi rumah tangga penerima PKH di Desa Girirejo Kecamatan Imogiri Kabupaten Bantul adalah96,04\%, artinya tingkat konsumsi energi rumah tangga penerima PKH dalam kategori cukup.Tingkat ketahanan pangan rumah tangga penerima PKH di Desa Girirejo Kecamatan Imogiri Kabupaten Bantul adalah rentan pangan.

\section{Saran}

Untuk meningkatkan pendapatan rumah tangga penerima PKH di Desa Girirejo hendaknya ada alternatif bantuan selain dalam bentuk BPNT (Bantuan Pangan Non Tunai) yaitu dengan pelatihan ataupun pemberian keterampilan kepada penerima manfaat PKH.Untuk memperbaiki nilai Tingkat Konsumsi Energi (TKE) hendaknya dilakukan penyuluhan untuk menambah pengetahuan anggota rumah tangga mengenai gizi, yang diharapkan dapat mampu memperbaiki pola pangan yang dibutuhkan dari sisi kuantitas maupun kualitas.Dukungan pemerintah dan keterlibatan masyarakat desa diperlukan untuk meningkatkan ketahanan pangan di desa Girirejo dengan menggencarkan kembali 6 Program Ketahanan Pangan yang terdiri dari Program Simpan Pinjam, Lumbung Pangan, Kelembagaan KWT, Boga Sehat, PAUD, dan BKL (Bina Keluarga Lansia).

\section{DAFTAR PUSTAKA}

Adriani, Merryana dan Wirjatmadi, Bambang. (2012). Pengantar Gizi Masyarakat.Jakarta : Kencana.

Ambarsari, Erlin Ratna. (2017). Analisis Ketersediaan Pangan Pokok dan KonsumsiEnergi Rumah Tangga Petani di Desa Tuksono Kecamatan Sentolo Kabupaten Kulon Progo. [Skripsi]. Yogyakarta : UPN "Veteran" Yogyakarta. 
Rahmansyah et.al., Analisis Ketahanan Pangan Rumah Tanggamiskin...

Arifin, Bustanul. (2007). Diagnosis Ekonomi Politik Pangan dan Pertanian. Jakarta : PT. Raja Grafindo.

Damayanti, Lien. (2007). Faktor-faktor yang mempengaruhi tingkat ketahanan pangan desa. Jurnal Agroland 14 (3) : 217 - 222.

Desa Girirejo. (2019). Monografi Desa Girirejo. Bantul : Desa Girirejo.

Dinas Pertanian Pangan Kelautan dan PerikananBantul Bidang Ketahanan. (2019). Desa Mandiri Pangan Kecamatan Imogiri. Bantul:Dinas Pertanian Pangan Kelautan dan PerikananBantul Bidang Ketahanan.

Fagi, Achmad. (2013). Ketahanan Pangan Indonesia dalam Ancaman. E-jurnal litbangpertanian.11 (1) : 11-25.

Fauzi, Muhammad, Kastaman, dan Pujianto. (2019). Pemetaan Ketahanan Pangan pada Badan Koordinasi Wilayah I Jawa Barat. Jurnal UNPAD 1, (1), :1-10.

Mulyo J.H., Sugiyarto, dan Widada, A. W. (2015). Ketahanan Pangan Rumah Tangga Tani Daerah Marginal di Kabupaten Bojonegoro. Jurnal Agro Ekonomi Vol. 26/ No. 2 : 121-123. Yogyakarta : UGM.

Nuraini Hikmah. (2013). Meningkatkan Ketahanan Pangan dalam Masyarakat. E-jurnal Unsera 2(2) : 1-10.

PKH Jogja Istimewa, "Sosialisasi Program Perlindungan dan Jaminan Sosial" Sawiji Greget Sengguh Ora Mingkuh, https://pkhjogjaistimewa.com/2018/04/19/sosialisasi-program-perlindungan-dan-jaminansosial/ (diakses pada tanggal 6 Maret 2018)

Prasetyaningtyas, Dewi. (2017). Hubungan Antara Ketersediaan Pangan dengan Keragaan Pangan Rumah Tangga Buruh Tani. E-jurnal UNAIR 12, (2) : 149-155.

Putri, Arya Dwiandana. dan Setiawina, Nyoman D. (2013). Pengaruh Umur, Pendidikan, Pekerjaan terhadap pendapatan Rumah Tangga Miskin di Desa Bebandem. E-Jurnal EP UNUD, 2 [4] :173-180.

Purwaningsih. (2008). Ketahanan Pangan: Situasi, Permasalahan, Kebijakan, DanPemberdayaan Masyarakat. Jurnal Ilmu Ekonomi dan Pembangunan,9, 1: 48

Rachman, Handewi dan Ariani, Mewa. (2002). Ketahanan Pangan: Konsep,

Pengukuran dan Strategi. Bogor : Forum Penelitian Agro Ekonomi, 20.1 : 12-24.

Sinaga, Ilham. (2012). Penggunaan Pangsa Pengeluaran Panga sebagai Indikator Komposit Ketahanan Pangan. e-jurnal SOCA (Sosial Ekonomi Pertanian), 7 (3) : 1-22.

Sugiyono. (2016). Metode Penelitian Kuantitatif, Kualitatif, dan Kombinasi (Mixed Methods). Bandung : Alfabeta.

Suharyanto, Heri. (2011). Ketahanan Pangan. Jurnal Sosial Humaniora, 4 (2), : 26-30.

Wahyuni. (2012(. Analisis Ketahanan Pangan Rumah Tangga Miskin di Kabupaten Sukoharjo. Surakarta : Universitas Sebelas Maret [Skripsi]. 